\title{
The Effects of Liquidity, Firm Size, and Profitability on the Firm Value with Mediating Leverage
}

Idah Zuhroh

Faculty of Economics and Business, University of Muhammadiyah Malang

\section{Abstract}

The objective of this present research is to obtain empirical evidence of the effects of leverage in mediating the firm size, profitability and liquidity on the firm value. The object of the research was go public property and real estate firms in the Indonesia Stock Exchange in the period of 2012-2016. Thirty one firms serving as the sample were taken using a purposive sampling method. A path analysis with software Linear Structural Relationship (LISREL) version 8.8 was employed to analyze the data. The results of the research showed that it was merely profitability variable which directly gave a significant and positive effect on the firm value. Whereas liquidity and size variables directly gave

Corresponding Author: Idah Zuhroh

idahzuhroh.umm@gmail.com

Received: 10 February 2019

Accepted: 14 March 2019

Published: 28 March 2019

Publishing services provided by

Knowledge E

(c) Idah Zuhroh. This article is distributed under the terms of the Creative Commons

Attribution License, which permits unrestricted use and redistribution provided that the original author and source are credited.

Selection and Peer-review under the responsibility of the ICIEBP Conference Committee.

\section{G OPEN ACCESS} a negative, although insignificant effect. The results of the testing proved that leverage is a variable which mediates the effect of liquidity, size and profitability on the firm value.

Keywords: liquidity, Leverage, firm size, profitabilit, firm value.

\section{Introduction}

Improving a firm value is made as an effort to maintain its excellence (Hermawan and Mafu'ah, 2014) and to keep its operational continuity so that the stakeholders' profit and prosperity may be improved (Febrianti, 2012).

Firm value plays a very important role for the firm, because if a firm value is high it will be followed by high prosperity for its stakeholders. Therefore, such a high firm value is really deserved by the owners of the firm in order to show their high prosperity (Suharli, 2006).

Firm value also reflects the investors' evaluation of the success of a firm and it is often related to the increase in the stock exchange price. Investors will make various analyses to ensure that the stock exchange they hold will give positive returns (Sujoko and Soebiantoro, 2007). The expectation of incomes the investors will receive in the future as reflected in the indicators of the market evaluation as a whole may be observed in the present firm value. (Meidiawati, 2016). 
A high firm value is not only paid attention by the firm and the investors but also by the creditors and the government (Herawaty, 2009). The firm value serves as a positive sign for the creditors to give Ioan (Manoppo and Ari, 2016). Moreover, it also reflects that the firm has a high ability in paying all of its obligations so that the creditors will be safe or are avoided from any default risks.

Any failure in the firm value maximization is caused by some incompetencies of the firm in implementing the determinants of the firm value(Ernawati dan Widyawati, 2016).

Firm value maximization is greatly influenced by the availability of and access to either external or internal firm fund sources (Safitri dan Wahyuati, 2015).

Saraswathi et al. (2016) stated that the leverage ratio plays an important role in improving a firm's performance and productivity. Leverage also reflects a firm's ability in managing fixed cost assets that produce returns to the owners of the firm (Moeljadi et al., 2015).

Leverage plays an important role in maximizing firm value (Welley and Untu, 2015). The addition of corporate debt may function as the tool for controlling the cash freely by the management. The increased control of fund will improve the firm's productivity and performance so that it will give impacts on the strengthening firm value as reflected through the increase in the stock exchange price (Mediawati, 2016).

Putri and Ukhriyawari's (2016) and Hermuningsih's (2012) research results showed that leverage gives positive and significant effects on the firm value. While Sujoko and Soebiantoro's (2007) and Wulandari's (2013) research results show different result, namely, leverage gave significant negative and significant effects on the form value. A firm with great debt also has a great debt cost. This burdens that firm and it in turn may decrease the investors' trust level (Thaib dan Dewantoro, 2017).

Firm size also plays an important role in optimizing firm value. Denziana and Monica (2016) states that firm value is an indicator of the firms' financial strength in supporting its performance. A big firm possesses some strengths: among others facilities to access to funding, (Dewi and Wirajaya, 2013) strategies in minimizing risks (Chen and Chen, 2011) and opportunities in obtaining greater benefits and better prospects in enterprises (Soliha, 2002).

The positive effect of firm size on the access to the funding source according to Pantow et al. (2015) may improve the investors' confidence of the increase in the firm value reflected in the stock exchange price. Higher size of a firm is considered to be easier to get sources of funding either for the operational costs or for the development of the firm. An expectation of the improvement of the firm will be followed by the investors' strengthened confidence to increase the stock ownership of the concerned 
firm. Strong demands for the firm stock will give further impacts on the increased stock price.

Some results of empirical studies on the effects of the firm size on the firm value with the object of firms in Indonesia have not been consistent. As reference, Ernawati and Widyawati's (2016) and Rompas's (2013) research results showed that firm size has positive and significant effects on firm value. Meanwhile, the research results made by Khumairo et al (2016) and Haryadi showed the contrary that firm value has a negative effect of firm value.

Firm value may also be explained from the firm profitability. Dewi and Wirajaya's (2013) research results show that profitability a firm earned may influence the firm value. It is in line with the investors' motive in any investment: gaining returns consisting of yield and capital gain (Agustina, 2013). It is in line with the explanation made by Setiadewi and Purbwangsa (2014) that a firm which is successful in increasing its profitability will improve the investors' confidence to give their fund to be managed by the concerned firm.

Profitability is known as the ratio of the management's effectiveness coming from the sale and the investment (Hermuningsih 2012). High profitability shows a good prospect of the firm so that investors will positively respond to the signal by increasing the stock price and the firm value (Sujoko dan Soebiantoro, 2007).

Return is an investor's main motive in his/her investment. Increased profit a firm makes will improve the return an investor receives so that a firm should always try to improve its profitability so that its stock may still interest the market (Mahendra et al (2012)

Another factor that may influence the firm value is liquidity or a firm's ability in paying its short-term obligations (Ernawati dan Widyawati, 2016). This is also expressed by Owolabi et al. (2012) that liquidity plays an important role in a firm's success.

Firm value is also influenced by a firm's leverage. However, empirical evidence of the firms in Indonesia is divided into two groups. The first group proved that that leverage is a mediating variable of liquidity, size and profitability in explaining any firm value changes. Some researchers finding the results are among othersHermuningsih (2012), Mulyani et al. (2017), Thaib dan Dewantoro (2017).

The second group stating that leverage is not a mediating variable of firm size, liquidity, and profitability is among others Wulandari(2013), Rubiyani (2016), Andanika and Ismawati(2017).

It is a replication of the research made Khumairoh et al. (2016) testing the leverage, firm size and profitability against the firm value. What is important to distinguish this 
present research with the previous one is the addition of liquidity as an exogenous variable and the analytical tool employed. The previous research merely make a partial testing for each variable, while this present research integrated the variables that had been examined into a path analysis.

Property and real estate firms need a large capital, thus the right financial decisions is very crucial. Leverage is an alternative acquisition of additional capital that can have a positive or negative effect. Property and real estate firms offer products which are used as resident area and asset investments. Based on this fact, the study is related to the market value of property and real estate is very interesting. This study can finally be drawn to its consistency in explaining the firm value and it can be compared with other sectors related to market response.

On the basis of the 2016 IDX data, 47\% property and real estate firms had the firm value (Tobin $Q$ ) of under 1, although in average the market value was 1.19. This shows that $47 \%$ firms in the property and real estate sector was not able to manage their assets well so that the investors undervalued the firms for their real book value.

The explanation of the changes of the firm value need further studies to ensure the decision makers to make proper decisions. The management may intervene the independent variables to either maintain and push the increase of the firm value. Meanwhile, investors will be able to make use of the results of the firm' estimation of the firm value as the basis for investing, buying, selling or maintaining their stock ownership.

On the other hand, the research results may encourage the development of financial literature, especially the study on the firm value in Indonesia of which the results of the findings have still varied.

\section{Literature Review}

\subsection{Firm value}

Firm value is a firm value which is firm fair value delineating the investors' evaluation of certain issuers so that the firm value is the investors' perception which is always related to the stock price (Soliha, 2002; Gultom, 2013; Languju, 2016).

Firm value is an important concept of investors namely as indicators of the market evaluation of a firm as a whole (Nurlela, 2008) therefore, firm value is defined as the firm selling price considered to be adequate by the prospective investors when the firm will be liquidated (Wahyudi dan Pawestri, 2006; Rahmawati, 2015) 
Firm value means a reflection of the performance attainment in operating the firm from its establishment up to now (Nugraha, 2016), Sundari (2013), Sukirni (2012).

Investors who evaluate that a firm has a good prospect in the future tend to buy the stocks of the firm. As a result, high demands for the stocks cause the stock price to be higher since investors give a high value to the firm.

One of the ratios that may be used to value a firm value is Tobin's $Q$. According to Dewi (2014), Tobin's $Q$ is a combination of values of tangible and intangible assets. The value of the Tobin's $Q$ for a firm ranges from 0 to 1 , showing that the cost for the substituting the firm assets exceeds the firm market value so that it means that the market values the firm too low. The value of Tobin's $Q$ above 1 shows that the market value of the firm exceeds the noted value of the firm assets.

According to Prasetyorini, (2013b), an analysis of Tobin's Q which lower than 1 shows that that the book value of the firm's assets is higher than its market value. Therefore, the company will become the target of acquisition or liquidation since the stock of the firm is undervalued. Logically, the buyers of the firm will get the assets in a lower price than if the assets are resold.

On the contrary, if the Tobin's $Q$ value is higher than 1 it shows that the market value of the firm is higher than its assets book value, indicating that the firm has a high potential growth that makes the assets of the firm overvalued.

\subsection{Profitability}

Profitability is the end result of a number of policies and decisions of the firm management (Bringham dan Weston, 2011). Profitability ratio is usually made to measure the success of a firm and indicators to evaluate the manager's performance.

In this present research, profitability is represented by ROE (return on equity). ROE is a measurement of incomes for the owner of the firm (either ordinary stockholder or preferred stock) over the stock invested. The higher this ratio value, the better for the stockholder it will be.

\subsection{Leverage}

Leverage is the effect coming from the use of long-term and short-term financing made by the firm (Sari dan Priyadi, 2017).

Leverage gives a picture of a firm's capital structure, so that the risk of a loan that is uncollectible may be detected (Prayoga and Almilia, 2013). A firm's leverage is proxied 
by debt to equity ratio. Debt to Equity Ratio (DER) portraits a whole debt and a whole capital in the firm funding and the level of the firm in fulfilling all its obligations through the modal it possesses. The higher the DER, the higher the percentage of foreign capital is used in the firm's operational cost (Sambora, 2014).

Harianto (2016) proved that Debt to Equity Ratio has positive and negative effects because there are some risk factors in reaching profits a firm expects and in continuing the firm's activities.

\subsection{Liquidity}

Liquidity is the ability of a firm to fulfill its obligations. Firm liquidity is shown by the amount of the currents asset namely the assets which are easily changed into cash, such as cash, securities, credits, stocks.

Liquidity is more focused on the ability of a firm to pay its current liabilities so that in this case the firm has enough internal fund to finance its operational cost.

"Current ratio is a ratio of the measurement of the level of a firm's ability in paying off short-term obligations or debts that will mature or in other words the number of the current assets possessed to pay all current liabilities that will mature." The higher the number of the liquidity, the more liquid the bank will be.

\subsubsection{Firm size}

According to Atmaja (2008) firm size is a scale that classifies the size of a firm using various modes: total assets, log size, stock market value, total sales and the like. Higher total assets and sales of the firm show the turnover of funds in the firm. The higher the total assets, the greater the capital the firm invests. On the basis of the descriptions, it can be stated that firm size is the number of assets a firm hold.

\subsection{Pecking order theory}

Pecking order theory is one of the theories underlying decisions of a firm's funding. Myers (1984) proposes the reasons of the tendency shown by a firm in determining its funding sources.

Myers (1984) explained that funding priorities based on the pecking order theory follow the following funding order 1) The firm prefers funding from internal sources. 2) The firm adjusts the target of the dividend payment to the opportunities of investment. 
3) External fund will be used when it is really needed where the safety priority is through debt and the last choice is through the issuance of new equities.

The idea of the Pecking Order Theory is based on the assumption of information asymmetry. The manager possesses more complete information about the firm. The issuance of equities as the investment funding source is meant as the bad news (Myers dan Majluf, 1984).Investors assume that the issuance of new equities cause the firm value to decline.

Bringham and Weston (2011) explained that the issuance of securities needs need a lower cost than the issuance of new stocks..Therefore, a firm will choose to issue debts for the cost efficiency.

According to the Pecking Order Theory, the use of debt may cause benefits, cost, and risk. An optimal use of debt by paying attention to the characteristics of the firm *asset, market share and profit ability) may reduce risks of failures in fulfilling obligations so that the firm may avoid any risks of the declining trust from investors that may cause the reduction of the firm value.

\subsection{Trade off theory}

According to Brealey et al. (2006), trade-off theory is known as an optimal capital structure. In this theory, a firm will try to increase its debt level into a certain point, where the benefits of the protection of additional interest tax may be traded off by cost addition of financial problems."

Bringham and Weston (2011) explained that the Trade Off Theory is a capital structure theory that the firm exchanges the tax benefit with problems caused by some potentials of bankruptcy over the use of debt.

The trade off theory explains that a firm with its capital structure without debts or a firm with its capital structure funded by debts is a bad firm. A firm without debts in its capital will pay higher taxes than that with debts and this will influence the firm value.

A firm with a capital structure dominated by debts is in a bad condition since it should pay the interest expense on debt so that its interest will be lower since it is used to pay the interest expense. The firm should trade off taxes and financial distress cost in using its debts. This theory portrait cost trade off problems using the value of interest tax protection resulted in by debts. Therefore, a firm should trade off the amount of its debts and its own capital. 


\subsection{Developing a hypothesis of the effects of liquidity on leverage}

Liquidity is a reflection of the firm's ability in paying its short-term obligation. Higher liquidity shows higher current assets than its current obligations a firm possesses.

The concept of the Pecking Order Theory explains that a firm with a high liquidity level shows that it has enough current asset to finance its operational cost without borrowing fund from other sources, so that the firm will lower its debt portion in its capital structure arrangement.

Wenny (2015) expressed that a firm with high liquidity level possesses a great internal fund to finance its activities so that it does not need any external fund either in the form of debt or stock issuance.

The statement of this Pecking Order Theory is reinforced by Güner (2016), Primantara and Primantara, (2016), Wirjawan (2015). Based on the descriptions above, the hypothesis proposed is as follow:

H1: Liquidity gives negative and significant effects on leverage.

\subsection{The effect of firm size on leverage}

Firm size represents the size of a firm. Sale is one of the indicators that may be used to know the size of a firm so that a firm with a high sale may be categorized into a great firm. A great firm in general possesses a great sale level and produces a great profit level too. The greater a firm, the higher fund it needs to finance its operational cost.

A Pecking order theory explains that a great firm has enough internal fund to finances its need for fund, so that it will reduce the portion of its fund use from external sources. The greater the size of a firm, the lower its capital structure will be.

Research results made by Güner (2016), Yoshendy et al. (2016) and Handoo, Sharma (2014) and Wirjawan (2015)prove that firm size has negative effects on leverage.

On the basis of the descriptions above, the following hypothesis is proposed:

H2: Firm size has negative and significant effects on leverage

\subsection{The effect of profitability on leverage}

Profitability is the reflection of a firm's ability in producing profit. The order of the use of the firm fund according to the Pecking order theory is as follows: first it is through internal funding so that when the profit a firm produces increases, it will have enough 
fund to finance its operational cost. Therefore, the firm will limits the use of its debt. This is reinforced by research results made by Handoo and Sharma (2014), Güner (2016) and Hermuningsih (2014a), Wirjawan (2015). Based on the descriptions above, the following hypothesis is proposed:

H3: Profitability has negative and significant effects on leverage

\subsection{The effect of leverage on firm value}

The Pecking order theory says that higher use of debt will reduce the firm value. Increased debt will increase the risk of a firm's income stream, where incomes are influenced by external factors while debts result in fixed loads regardless of the incomes.

The higher the debt, the higher possibility of a firm is not able to pay its obligations in the form of interest and the principal. The risk of bankruptcy will be higher since the interest will increase, exceeding the benefits of tax savings. This statement is supported by research results made by Sujoko and Soebiantoro (2007), Khumairoh et al. (2016), and Dewi and Wirajaya (2013). Based on the descriptions above, a hypothesis proposed is as follows:

H6: Leverage has negative and significant effects on the firm value.

\subsection{The effect of profitability on firm value}

The effect of profitability on firm value is explained by the signal theory. The increase of profitability shows a firm's increased ability in gaining profit for its shareholders. Great profit shows a firm's greater ability to pay its dividends, so that it will increase the firm value.

Profitability is the main attraction for the firm's owners (stockholders) since it is the results gained through the efforts made by the management over the fund invested by the stockholders and it also reflects the dividends in accordance with their shares namely the money they reinvest and the money they pay as cash dividends or stock dividends to them (Jusriani dan Rahardjo, 2013).

According to Sofyaningsih dan Hardiningsih (2011), firm with high profitability will be able to result in high profit, so that the firm's equities will be kept to be positive even increased due to the increased profit retained by the firm. In this case, the firm has an enough internal funding source to pay the interest and this causes its interest burden gets lower so that the earned profit may be distributed to the stockholders in 
the form of dividends or retained to reinforce the capital. It is in line with the explanation offered by Dewi and Wirajaya (2013), (Hermuningsih, 2014a), Safitri (2015). Based on the descriptions above, a hypothesis is proposed:

H7: Profitability has positive and significant effects on the firm value.

\subsection{The effect of liquidity on firm value}

A firm's liquidity delineates the level of a firms' ability in fulfilling its short-term obligations. Based on the Signaling theory, liquidity shows a firm's ability in paying its short-term obligations so that it will make use of it as the sign to the investors. It is supported by the results of researches made by Wulandari (2013), Safitri (2015) dan Rompas (2013) that proved that the increase of a firm's liquidity will be followed by the increase of the firm value. On the basis on the descriptions, the following hypothesis is proposed:

H8: Liquidity has positive and significant effects on firm value.

\subsection{The effect of the firm size on the firm value}

Firm size is a reflection of a firm's high commitment to always improve its performance, so that the market will be willing to pay more to gets its stocks since the market believes to get profitable return from the company.

The research results made by Sofyaningsih and Hardiningsih (2011) and Nurhayati (2013) showed that the increase of a firm size will improve the stock value of the firm and this in turn will give effects on the increase of the firm's stock value. The firm with a great business scale is considered to be able to return the fund to its investors. In this context, the firm is thought to have higher abilities to manage its business than those of small firms. Based on the descriptions above, a hypothesis is proposed:

H9: The firm size gives positive and significant effects on the firm value.

\subsection{The effect of liquidity on the firm value through leverage}

Liquidity is a reflection of a firm's ability in fulfilling its short-term obligations. According to the Pecking Order Theory, high liquidity shows that a firm possesses high internal fund sources so that this firm will reduce the portion of the use of its debts. Gurner's (2016) research result found an evidence that there is a negative effect between liquidity and leverage in non-financial firms in Turkey. 
Increased internal funding reflected in high liquidity will cause a firm's leverage to reduce so that the risks of firm's financial distress will also go down. Sujoko and Soebiantoro (2007) stated that the increase in debt will be followed by the decrease in the firm value. This condition is understandable since the increased debt will cause the higher interest burden, moreover, the firm should also bear the bankruptcy cost. This will give negative signals to the investors on the high risk the firm will bear where this will then cause low demand for the firms' stocks so that the firm value will also decrease.

Shelly (2013) proved that leverage is able to mediate the effects of liquidity on a firm value. based on the descriptions above, the following hypothesis is formulized:

H10: Liquidity gives effects on the firm's leverage through leverage as the intervening variable.

\subsection{The effect of the firm size on the firm value through leverage}

Pecking order theory says that a large size firm reflects that its high funding ability is from its operational cost and this will cause the firm to reduce the level of its debt use.

Mahardhika dan Aisjah (2013) said that the funding sources of great companies are from their internal funding namely the results of production activities so that the use of external sources will be limited. High sales supported by efficiency will help the firm gain higher profit so that cost for business expansion may be covered $y$ the profit.

High profit a firm gains will reduce the portion of its debt use so that the cost or the risk the firm face will also decrease. This certainly will make the firm get higher profit.

The sign will be positively responded by investors through high demands for the stock so that the firm's stock price will increase and the firm value will also increase.

Sujoko dan Soebiantoro (2007), proved that the increase in a firm's debt will lower down the firm value. Hermuningsih (2014b) and shelly (2013) found an evidence that capital structure is an intervening variable for the firm size over the firm value. based on the description above, a hypothesis is formulized:

H11: Size has positive and significant effects on the firm value with leverage as intervening variable 


\subsection{The effect of profitability on the firm value through leverage}

A firm's ability in gaining profit from its operational activities is known as profitability. A high level of profitability expresses the return on investment so that the firm possess enough internal fund to finance any expenses needed by the firm so that the portion of the debt use automatically will decrease. The decreased portion of the debt use certainly will give impacts on the decrease in the bankruptcy risk the investors face.

Amirya dan Sari (2007) and Hermuningsih (2014b) proved that leverage is able to mediate profitability over the firm value negatively and significantly. Based on the descriptions above, the hypothesis is formulized as follows:

H13: Profit gives positive and significant effects on the firm value with leverage $s$ the intervening variable.

\section{Research Method}

It was a causal comparative research namely a research type where the characteristic of the problem is in the form of the cause and effect relationship between or among two or more variables. Causal comparative research is an ex post facto research type namely a research type with the collected data after facts or events.

The type of the data used in this present research was secondary data in the form of the financial data from property and real estate firms from 2012-2016.

The research population was firms working in the property and real estate sector listed in the Indonesia Stock Exchange from 2012 to 2016.

Non probability sampling design with judgment sampling method was employed. Judgment sampling is one type of the purposive samplings where the sampling is made based on the evaluation of some characteristics of the population members that are adjusted to the intention of the research (Kuncoro, 2013).

The sampling criteria adopted were as follows: 1) Property and real estate firms continuously listed in the Indonesia Stock Exchange in the period of 2012-2016; 2) Property and real estate firms that possessed complete financial reports in the period of 2012-2016; and 3) Property and real estate firms that did not have negative profit in the period of 2012-2016.

Based on the criteria, the number of sample in this present research could be explained in Table 1 below. 
TABLE 1: Table of sampling.

Forms working in the property and real estate sector listed in the Indonesia Stock Exchange

Property and real estate firms continuously listed in the Indonesia Stock Exchange in the period of 2016-2016

Property and real estate firms possessing complete financial reports in the period of 2012-2916

Property and real estate firms that did not possess negative profit in the period of 2012-2016

Number of samples for 5 years

\subsection{Variable dan operational definition}

In this present research five variables were employed: firm size, liquidity, profitability, leverage and firm value. Each research variable operationally can be defined in Table 2.

TABLE 2: Operational Definition.

\begin{tabular}{|c|c|c|}
\hline Firm Value (Z) & Performance of stock market over the book value & Tobin $Q \frac{\text { MVE }+ \text { Debt }}{\text { Total Assets }}$ \\
\hline Leverage(Y) & Percentage of total debt to finance the assets & DER: $\frac{\text { Total Debt }}{\text { Total Capital }}$ \\
\hline Profitability $\left(X_{1}\right)$ & $\begin{array}{l}\text { Ability in managing the firm's assets to earn profit } \\
\text { over sales }\end{array}$ & ROA: $\frac{\text { Net Profit }}{\text { Total Assets }}$ \\
\hline Liquidity $\left(\mathrm{X}_{2}\right)$ & Firm's ability in pay off its short-term debts & CR: $\frac{\text { Cur. Assets }}{\text { Cur. Obligations }}$ \\
\hline Size Firm $\left(X_{3}\right)$ & Determining the scale of firm based on total sales & Ln Total sales \\
\hline
\end{tabular}

\subsection{Analysis method}

Path analysis is a technique of analyzing a cause-effect relationship happening to a multi-linear regression, when exogenous variables give effects on exogenous variables not only directly but also indirectly (Ghozali dan Fuad, 2005).

Path analysis represents problems in the form of pictures and determines structural equations stating the relation among variables in the path variable.

Path diagram may be used to count direct and indirect effects from exogenous variables on an endogenous variable. The effects are reflected in what is caller a path coefficient, where mathematically, the path analysis followes a structural model. 
The technique of the data analysis adopted in this present research was a path analysis with multi-regression model using the mediating variables

A path analysis with a multi-regression model for the mediating variables was employed as the technique of data analysis. The software of Linear Structural Relationship (LISREL) was made use of. Path analysis is defined as a regression expansion model used to test the fit of the correlational matrices with two or more cause-effect relationship models a researcher compares.

Path Analysis is used to analyze the pattern of relationship among variables with the goal of understanding direct and indirect effects of a set of independent variables on dependent variables. In this path analysis, there is a variable playing double roles namely as the independent variable in a relation, but as the dependent one in another relation, remembering that there is a staged causality relationship.

Path analysis wants to test a regression equation involving some exogenous (independent) variables and endogenous (dependent) variables simultaneously that it is possible to test the intervening variable. Moreover, this path analysis may also measure direct relationships among variables in the model or indirect relationships among variables in the model. The path analysis was made with the following steps:

\subsection{Equation model}

In line with the framework of mind and the hypotheses proposed, the following model in the form of equation and a path diagram was established.

$$
\begin{gathered}
Y=\rho y x_{1} X_{1}+\rho y x_{2} X_{2}+\mathrm{P} y x_{3} X_{3}+\varepsilon_{1} \\
Z=\rho z x_{1} X 1+\rho z x_{2} X_{2}+\rho z x_{3} X_{3}+\rho z y Y+\varepsilon_{2}
\end{gathered}
$$

Note:

Z: Firm value

Y: Leverage

$\mathrm{X}_{1}$ : Profitability

$\mathrm{X}_{2}$ : Liquidity

$\mathrm{X}_{3}$ : Size 


\subsection{Assumption testing}

The second step of the path analysis was the testing of the assumption underlying the path analysis. (Ghozali and Fuad, 2005) The assumptions that should be fulfilled in the LISREL are normality and multicollinearity.

\subsection{Normality testing}

Normality is a form of a data distribution in a single matrix variable to result in a normal distribution. If a data distribution does not form a normal distribution, the data are abnormal, and the opposite. If a normal distribution is not fulfilled and the deviation of the normality is great, all results of the t-test and the like should be counted with the assumption that the data are normal.

Normality test is divided into two: univariate normality and multivariate normality. Univariate normality is a normality test in the statistical application of the Linear Structural Relationship (LISREL), stating that the data are normal if the p-value in the skewness and curtosis is insignificant ( $p$-value $>0.05$ ). Multivariate normality, of which the assumption of multivariate normality is far more important than that of the univariate normality, states that data are normal simultaneously if the P-value is less than 0.05 ( $p$ Value $<0,05$ ).

\subsection{Multicollinearity testing}

The assumption of multicollinearity in the LISREL requires inexistence of perfect or high correlations among independent variables. The value of the correlation among the observed variables which are not allowed is 0.9 or higher.

\subsection{Linearity testing}

Linearity testing is aimed at understanding whether two variables have linear or insignificant relationship. This testing is usually used as a requirement in any correlational analysis or linear regression. The bases for the decision making in the linearity testing were as follows. First was based on the significance value. If the probability value > 0.05 , the relationship between variable $X$ and $Y$ is linear, and if the probability value $<0.05$, the relationship between variable $X$ and $Y$ is not linear. Second is based on the values of the F-count and F-Table. If the value of the T-count is lower than that of the F-table, the conclusion is that there is a significant linear relationship between 
variable $Z$ and $Y$. On the contrary, if the value of the F-count is higher than that of the F-table (F-count $>$ F-table), then the conclusion is that there is not a significant linear relationship between variable $\mathrm{X}$ and $\mathrm{Y}$.

In this present research, the linearity test would be processed using the SPSS, remembering that in LISREL, there are just normality and multicollinearity tests.

\subsection{Hypotheses testing}

In LISREL, there is no significance value that may directly show whether a relationship between a variable and others is significant. In each estimation of parameter in LISREL, there three information which is very useful: regression coefficient, standard error and T-value.

To know whether a relationship among variables is significant or not. The T-value should be higher than that of the T-table at a certain significance level. In this present research the significance level adopted was $5 \%$ and it can be seen from the output results of the diagram from LISREL. If the color of the line connecting among variables is red, the relationship was not significant. A significant relationship would produce a black line.

\section{Result and Discussion}

As mentioned earlier, high corporate value is the goal of firm because it reflects the ability to provide shareholder prosperity which is represented by a stronger stock market price. Table 1 shows that the value of property firms in the range of $0.28-4.47$ or on the average of the firm value is 1.345 . Investors are very optimistic about the performance of the firm so that valuing firms is higher than book value. However, it should be noted that the value of the firm varies greatly between firms and there is a tendency to fluctuate periodically.

Referring to theoretical and empirical studies, it is suspected that the changing in firm values are influenced by the changing in the financial performance variables, which are size, $\mathrm{CR}$ and ROA through leverage mediation.

The average value in each variable shows that the best practices in property and real estate industry or it can be used as a reference for individual firms. The statement of problem is why does the firm value is fluctuated (low or high)? Figure 1 shows the relevance of firm values to the financial performance of ROA, SIZE, DER and CR. 
TABLE 3: Descriptive Statistics.

\begin{tabular}{l|c|c|c|c|c|}
\hline Variable & N & Min. & Max. & Mean & Std. Dev \\
\hline ROA & 135 & 0.27 & 25.62 & 7.2301 & 4.92602 \\
\hline SIZE & 135 & 17.43 & 22.74 & 20.5332 & 1.31759 \\
\hline DER & 135 & 8.56 & 226.96 & 76.7121 & 45.35378 \\
\hline CR & 135 & 0.14 & 6.45 & 1.9602 & 1.13517 \\
\hline TOBIN & 135 & 0.28 & 3.68 & 1.3619 & 0.684 \\
\hline Source: IDX, 2012-2016 & & & & \\
\hline
\end{tabular}

The firm value has a pattern of the data movement that follows the independent variables including ROA and DER. Meanwhile, Size and DER have a positive direction. CR lacks a clear relationship pattern with firm value. It can be underlined that the figure described above only shows the relationship between variables that have not simplified the complexity of the influence of other variables that are considered constant. The next stage is to examine the hypothesis testing.

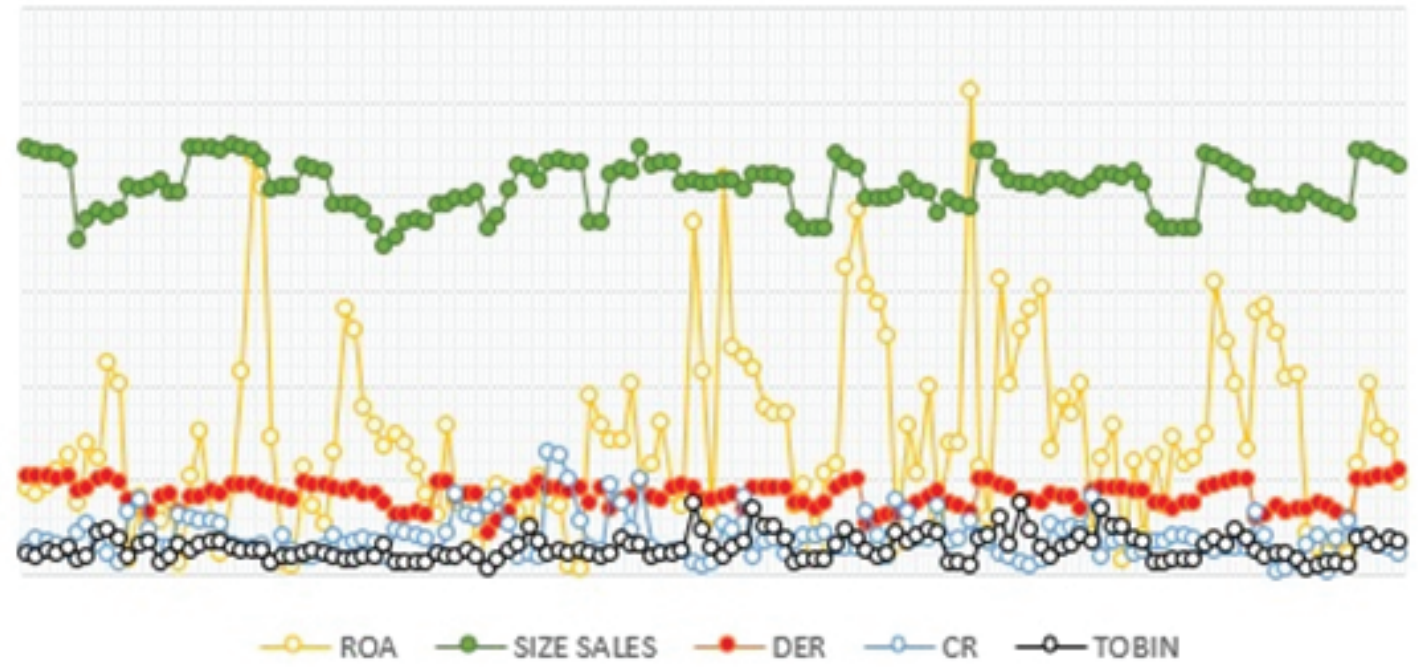

Figure 1: Relationship Pattern Between ROA, SIZE, DER, CR and Firm Value.

\subsection{Path analysis}

The testing of the data were conducted using a path analysis to test the effects of size, profitability and liquidity on the firm value, using leverage as the intervening variable. From the calculation using the LISREL 8.8, a path diagram may be produced as follows: 


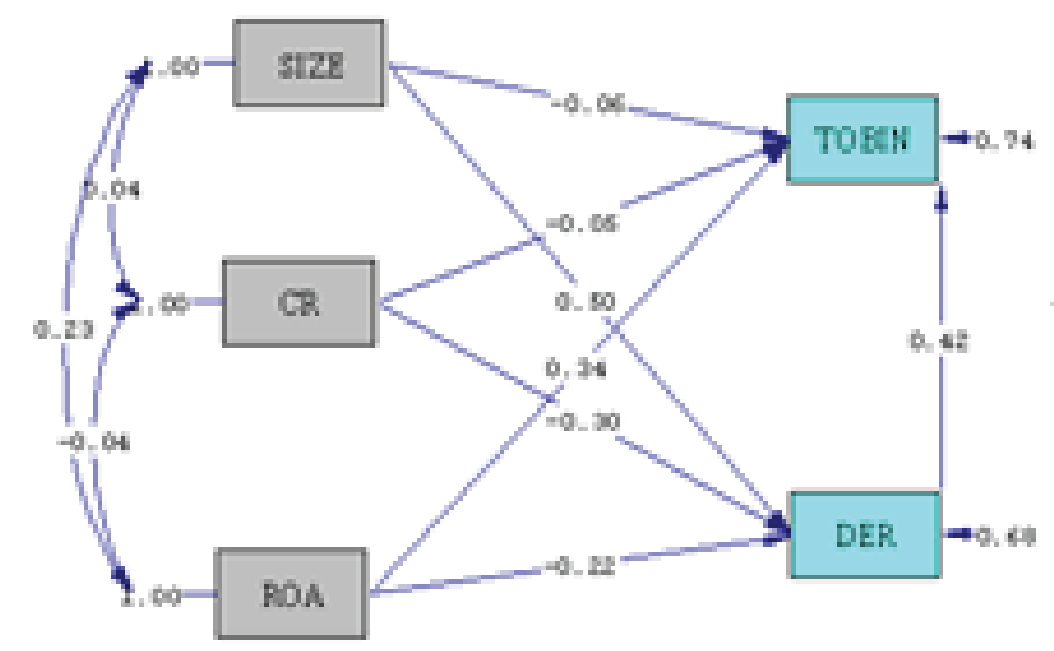

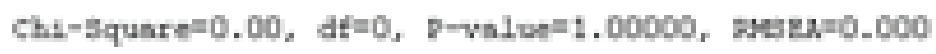

Figure 2: Estimator Parameter of Path Analysis.

\subsection{Goodness of fit model}

The result of testing the goodness of fit showed that the chi-square value was 0.00 and the P-value was 1 ( $P>0.05)$. According to Ghozali and Fuad (2011) the value of the chi-square is a measure of the goodness or the goodness of fit of a model and te value of the chi-square of 0 shows that the model has a perfect fit.

\subsection{T-test}

Based on the results of the data processing, the empirical equation model was as follows: 


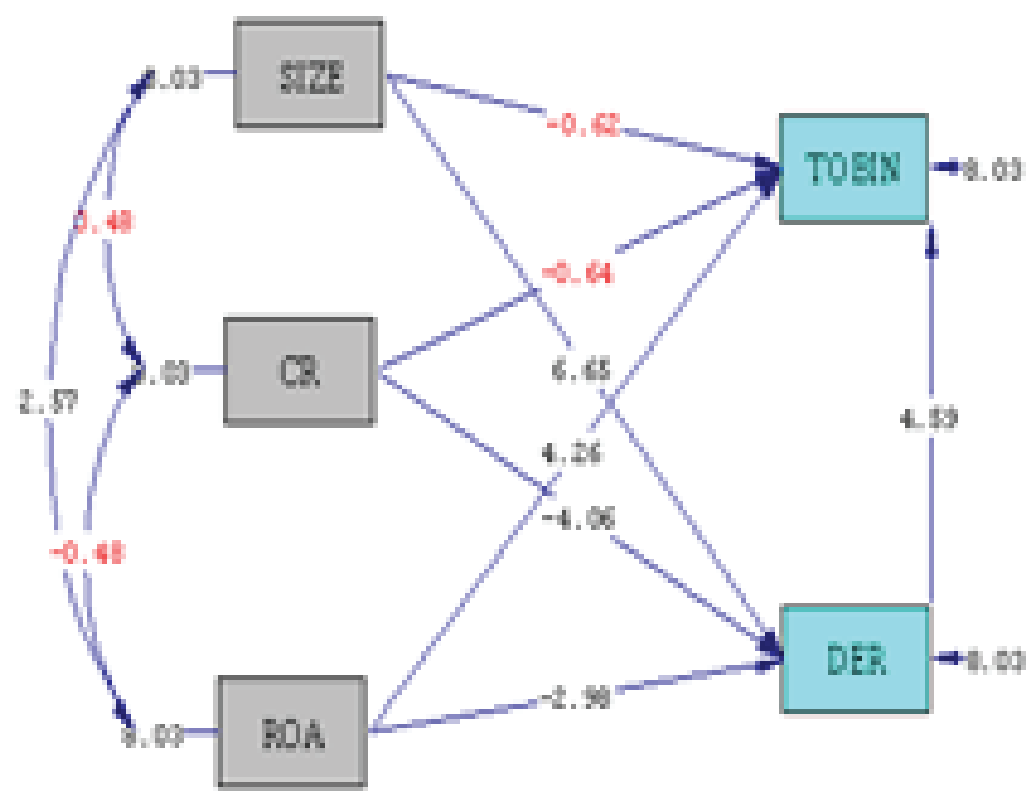

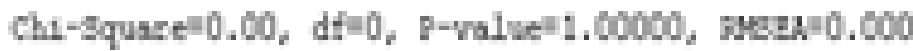

Figure 3: T-test of Path Analysis.

$$
\begin{aligned}
& \mathrm{TOBIN}=0.079 * S I Z E-0.10^{*} \mathrm{CR}+0.038^{*} \mathrm{ROA}, \\
& \begin{array}{lll}
(0.043) \quad(0.049) \quad(0.013)
\end{array} \\
& \begin{array}{lll}
1.83 & -2.15 & 2.97
\end{array} \\
& \text { Errorvar. }=0.42, R^{2}=0.14 \\
& D E R=15.42 * S I Z E-10.67 * C R-2.04 * R O A, \\
& \begin{array}{lll}
(2.32) & (2.63) \quad(0.69)
\end{array} \\
& \begin{array}{lll}
6.65 & -4.06 & -2.98
\end{array}
\end{aligned}
$$

The following is the result of the determination coefficient test using the program LISREL 8.80:

$$
\text { TOBIN }=0.0069 * \text { DER }-0.028 * S I Z E-0.031^{*} C R+0.052 * R O A,
$$

Errorvar. $=0.36, \mathrm{R}^{2}=0.26$ 
The first model had the $\mathrm{R}^{2}$ value of 0.26 where this value showed the ability of the variables size (Ln sales), liquidity (CR), Leverage (DER) and profitability (ROA) in explaining the change of the firm value variable (Tobin Q) of $26 \%$.

$$
\mathrm{DER}=15.42 * \mathrm{SIZE}-10.67^{*} \mathrm{CR}-2.04^{*} \mathrm{ROA}, \text { Errorvar. }=1212.09, \mathrm{R}^{2} \text { Ajusted }=0.32
$$

In the second model the $R^{2}$ value was 0.32 . This value showed the ability of the variable size (Ln sales), liquidity (CR), and profitability ( $R O A$ ) in explaining the change of the leverage value (DER) of $32 \%$.

\section{Direct Effects}

The effects of exogenous variables on the intervening and endogenous variables are presented in Table 4.

TABLE 4: Results of Coefficient Significance Test.

\begin{tabular}{l|c|c|c} 
Path & Coeff. & T-count $>1,96$ & Conclusion \\
\hline $\mathrm{CR} \rightarrow$ DER & $-0,30$ & $-4,06$ & Significant \\
\hline ROA $\rightarrow$ DER & $-0,22$ & $-2,98$ & Significant \\
\hline SIZE $\rightarrow$ DER & 0,50 & 6,65 & Significant \\
\hline SIZE $\rightarrow$ TOBIN Q & $-0,06$ & 0,62 & Insignificant Significant \\
\hline ROA $\rightarrow$ TOBIN Q & 0,34 & 4,26 & Significant \\
\hline CR $\rightarrow$ TOBIN Q & $-0,05$ & $-0,64$ & Insignificant Significant \\
DER $\rightarrow$ TOBIN Q & 0,42 & 4,59 & ignificant \\
Source: Research data processed, 2018 &
\end{tabular}

The liquidity variable gave a negative and significant effect on the leverage with the T-count of -4.06 ( $>1.96)$. This research result is in line with the pecking order theory that a firm with high liquidity will reduce its debt proportion since the firm has enough fund to finance its operational cost.

Firm size gave a positive and significant effect on the leverage. This research result is inconsistent with the pecking order theory explaining that a high scale firm in general possesses enough internal fund to finance its need for fund so that the firm will reduce the portion of the use of external fund.

Profitability gave a negative and significant effect on the leverage with the value of the T-count of $-2.98(>1.96)$. This research result is consistent with the pecking order theory that a firm prefers internal funding. A firm with high profitability will reduce its 
debt portion since its internal fund coming from the profit/profitability earned by the firm has been adequate to cover its operational cost.

Indirect effects of exogenous variables on the endogenous variables through the intervening variable may be known from the coefficient value.

TABLE 5: Direct and Indirect Effect.

Effect
Direct effect of the firm size variable
on the leverage
Indirect Effect of the firm size on the
firm value through Leverage
Total Effect
Direct effect of the firm liquidity
variable on the Leverage
Indirect effect of the liquidity on the
firm value through Leverage
Total effect
Direct effect of the firm profitability
variable on the Leverage
Indirect Effect of the firm profitability
through Leverage
Total Effect

\begin{tabular}{|c|}
\hline Number of Coefficient \\
\hline 0.50 \\
\hline$-0.06 \times 0.42(-0.0252)+$ \\
\hline 0.4748 \\
\hline-0.30 \\
\hline$-0.05 \times 0.42(-0.021)+$ \\
\hline-0.321 \\
\hline-0.22 \\
\hline $0.34 \times 0.42(0.1428)+$ \\
\hline-0.0772 \\
\hline
\end{tabular}

Based on these research results, it was shown that the firm size had a direct effect on the firm value that may be seen from the total effects that the estimated coefficient was 0.4748 .

Liquidity gave an indirect effect on the firm size that may be known from the total effect showing that the estimated coefficient was -0.321 .

Meanwhile profitability had an indirect effect on the firm value that may be known from the result of total effects showing that the estimated coefficient was -0.0772 .

From the research results, it can be concluded that leverage is an intervening variable for the profitability and the size and liquidity.

\section{Conclusion}

From the results of the data analyses applying the software LISREL 8.80 in 31 firms listed in the Indonesia Stock Exchange in the period of 2012-2016, two conclusions are made. Firstly, the profitability and leverage variables give positive and significant effects on the firm value. It means that the higher the profitability and leverage, the higher the 
firm value will be. Secondly, the leverage variable is an intervening variable for the size, liquidity and profitability.

Based on the findings above, it is relevant for the property and real estate firms to increase their leverage in order to improve the firm value. high leverage is followed by investors' strong trust marked by the increase in the firm value. The use of leverage may improve the firm's control over the use of the cash freely by the management. Moreover, it is the firms with good performance that will get loan.

These research results should be more deeply studied remembering that these have not answered the inconsistency of the findings about the impacts of leverage to the firm value. next researches should differentiate characteristics of firms, the control mechanism of the use of fund and the evaluation of the effectiveness of the fund management as the moderating variables reinforcing the impacts of leverage on the firm value.

\section{References}

[1] Agustina, S. 2013. "Pengaruh profitabilitas dan pengungkapan corporate social responsibility terhadap nilai perusahaan". Jurnal Akuntansi, Vol. 1, No. 1, hlm: 1-29.

[2] Amirya, M., dan A. Sari. Year. "Faktor-faktor yang mempengaruhi nilai perusahaan yang dimediasi oleh Leverage sebagai variabel intervening: sebuah perspektif Pecking Order Theory". Artikel dipresentasikan pada The 1 Accounting conference faculty of economic Universitas Indonesia, Depok.

[3] Andanika, A., dan I. Ismawati. 2017. "Pengaruh Profitabilitas Dan Growth Opportunity Terhadap Nilai Perusahaan Dengan Struktur Modal Sebagai Variabel Intervening Pada Perusahaan Yang Terdaftar Di Jakarta Islamic Index". Jurnal Iqtisaduna, Vol. 3, No. 2, hlm: 205-233.

[4] Anisyah, dan Purwohandoko. 2017. "Pengaruh Profitabilitas, Leverage, Ukuran Perusahaan dan Struktur Modal terhadap Nilai Perusahaan Pada Sektor Pertambangan yang Terdaftar pada Bursa Efek IndonesiaPeriode 2010-2015". Jurnal Manajerial Bisnis, Vol. Volume 1, Nomor 1, Agustus - November 2017 No., hlm: 34-46.

[5] Atmaja, L. S. 2008. Teori dan Praktik Manajemen Keuangan. Yogyakarta: CV Andi Offset.

[6] Brealey, Marcus, dan Myers. 2006. Dasar-Dasar manajemen keuangan perusahaan. Jakarta. : Erlangga.

[7] Bringham, E. F., dan J. F. Weston. 2011. Dasar-dasar Manajemen Keuangan Edisi 11 Buku 2: Terjemahan oleh Ai Akbar Yulianto. Salemba Empat. Jakarta. 
[8] Chen, L.-J., dan S.-Y. Chen. 2011. "The influence of profitability on firm value with capital structure as the mediator and firm size and industry as moderators". Investment Management and Financial Innovations, Vol. 8, No. 3, hlm: 121-129.

[9] Denziana, A., dan W. Monica. 2016. "Analisis Ukuran Perusahaan dan Profitabilitas Terhadap Nilai Perusahaan (Studi Empiris Pada Perusahaan Yang Tergolong LQ45 di BEI Periode 2011-2014)". Jurnal Akuntansi dan Keuangan, Vol. 7, No. 2, hlm: 241-254

[10] Dewi, A. S. M., dan A. Wirajaya. 2013. "Pengaruh struktur modal, profitabilitas dan ukuran perusahaan pada nilai perusahaan". E-Jurnal Akuntansi, Vol. 4, No. 2, hlm: 358-372.

[11] Dewi, I. R. 2014. "Pengaruh struktur modal terhadap nilai perusahaan (Studi pada sektor pertambangan yang terdaftar di BEl periode 2009-2012)". Jurnal Administrasi Bisnis, Vol. 17, No. 1, hlm: 1-9.

[12] Ernawati, D., dan D. Widyawati. 2015. "Pengaruh profitabilitas, Leverage dan ukuran perusahaan terhadap nilai perusahaan". Jurnal Ilmu dan Riset Akuntansi, Vol. 4, No. 4, hlm: 1-17.

[13] Febrianti, M. 2012. "Faktor-Faktor yang Mempengaruhi Nilai Perusahaan pada Industri Pertambangan di Bursa Efek Indonesia". Jurnal Bisnis Dan Akuntansi, Vol. 14, No. 2, hlm: 141-156.

[14] Ghozali, I., dan Fuad. 2005. Structural Equation Modelling, Teori, Konsep, dan. Aplikasi dengan Program Lisrel 8.54,. Semarang: Badan Penerbit UNDIP.

[15] Gultom, R. 2013. "Analisis Faktor-Faktor yang Mempengaruhi Nilai Perusahaan pada Perusahaan Farmasi di Bursa Efek Indonesia”. JWEM (Jurnal Wira Ekonomi Mikroskil), Vol. 3, No. 1, hlm: 51-60.

[16] Güner, A. 2016. "The Determinants of Capital Structure Decisions: New Evidence from Turkish Companies”. Procedia Economics and Finance, Vol. 38, No., hlm: 8489.

[17] Handoo, A., dan K. Sharma. 2014. "A study on determinants of capital structure in India". IIMB Management review, Vol. 26, No. 3, hIm: 170-182.

[18] Harianto, H. 2016. "Pengaruh Rasio Keuangan Terhadap Harga Saham Pada Perusahaan Manufaktur Yang Terdaftar Di BEl”. Jurnal IImu dan Riset Akuntansi, Vol. 2, No. 12, hlm.

[19] Haryadi, E. 2017. "Pengaruh size perusahaan, keputusan pendanaan, profitabilitas dan keputusan investasi terhadap nilai perusahaan”. Jurnal Akuntansi: Kajian IImiah Akuntansi (JAK), Vol. 3, No. 2, hlm: 1-22. 
[20] Herawaty, V. 2009. "Peran praktek corporate governance sebagai moderating variable dari pengaruh earnings management terhadap nilai perusahaan". Jurnal Akuntansi dan Keuangan, Vol. 10, No. 2, hlm: PP. 97-108.

[21] Hermawan, S., dan A. N. Maf'ulah. 2014. "Pengaruh Kinerja Keuangan Terhadap Nilai Perusahaan Dengan Pengungkapan Corporate Social Responsibility Sebagai Variabel Pemoderasi”. Jurnal Dinamika Akuntansi, Vol. 6, No. 2, hlm; 103-118.

[22] Hermuningsih, S. 2012. "Pengaruh Profitabilitas, Size Terhadap Nilai Perusahaan Dengan Sruktur Modal Sebagai Variabel Intervening”. Jurnal Siasat Bisnis, Vol. 16, No. 2, hlm: 232-242.

[23] _ 2014a. "Pengaruh profitabilitas, growth opportunity, struktur modal terhadap nilai perusahaan pada perusahaan publik di Indonesia”. Bulletin of Monetary Economics and Banking (Buletin Ekonomi Moneter dan Perbankan), Vol. 16, No. 2, hlm: 127-148.

[24] Khumairoh, H. Mulyati, dan N. Kalbuana. 2016. "Pengaruh Leverage, Profitabilitas, dan Ukuran Perusahaan Terhadap Nilai Perusahaan (Studi Empiris pada Perusahaan Garment dan Textile yang terdaftar di Bursa Efek Indonesia Tahun 2011-2015)". Artikel dipresentasikan pada Seminar Nasional dan The 3rd Call for Syariah Paper.

[25] Kuncoro, M. 2013. Metode Riset Untuk Bisnis Dan Ekonomi. 4. Jakarta: Erlangga.

[26] Languju, O. 2016. "Pengaruh Return On Equity, Ukuran Perusahaan, Price Earning Ratio dan Struktur Modal terhadap Nilai Perusahaan Property and real estate terdaftar di Bursa Efek Indonesia". Jurnal Berkala IImiah Efisiensi, Vol. 16, No. 2, hlm: 387-398.

[27] Lestari, N., dan R. C. Sapitri. 2016. "Pengaruh Intellectual Capital Terhadap Nilai Perusahaan". Jurnal Akuntansi, Ekonomi dan Manajemen Bisnis, Vol. Vol. 4, No. 1, July 2016, No., hlm: , 28-33.

[28] Mahardhika, B. P., dan S. Aisjah. 2013. "Pengujian Pecking Order Theory dan Trade Off Theory pada Struktur Modal Perusahaan (Studi pada Perusahaan Consumer Goods di Bursa Efek Indonesia)". Jurnal IImiah Mahasiswa FEB, Vol. 2, No. 2, hlm: 1-17.

[29] Mahendra, A., L. G. Sri Artini, dan A. Suarjaya. 2012. "Pengaruh kinerja keuangan terhadap nilai perusahaan pada perusahaan manufaktur di Bursa Efek Indonesia". Matrik: Jurnal Manajemen, Strategi Bisnis dan Kewirausahaan, Vol. 6, No. 2, hlm: 130-138.

[30] Manoppo, H., dan F. V. Arie. 2016. "Pengaruh Struktur Modal, Ukuran Perusahaan dan Profitabilitas Terhadap Nilai Perusahaan Otomotif yang Terdaftar di Bursa Efek 
Indonesia Periode 2011-2014". Jurnal EMBA: Jurnal Riset Ekonomi, Manajemen, Bisnis dan Akuntansi, Vol. 4, No. 2, hlm: 485-497.

[31] Meidiawati, K. 2016. "Pengaruh Size, Growth, Profitabilitas, Struktur Modal, Kebijakan Dividen Terhadap Nilai Perusahaan". Jurnal IImu dan Riset Akuntansi, Vol. 5, No. 2, hlm: 1-16.

[32] Moeljadi, M., K. Ratnawati, dan A. Afriani. 2015. "Pengaruh Variabel Fundamental dan Makroekonomi pada Struktur Modal dan Nilai Perusahaan (Studi pada Perusahaan Property dan Real Estate di BEI)". Jurnal Akuntansi Bisnis dan Manajemen, Vol. 22, No. 1, hlm: 35-49.

[33] Mulyani, S., D. Amboningtyas, dan A. Fathoni. 2017. "The Influence Of Liquidity, Profitability, Leverage On Firm Value With Capital Structure As Intervening Variable (In Plantation Sub Sector Company 2012-2016 Listed In BEI)". Journal of Management, Vol. 3, No. 3, hlm:1-11.

[34] Myers, S. C. 1984. "The capital structure puzzle". The journal of finance, Vol. 39, No. 3, hIm: 574-592.

[35] Myers, S. C., dan N. S. Majluf. 1984. "Corporate financing and investment decisions when firms have information that investors do not have". Journal of financial economics, Vol. 13, No. 2, hlm: 187-221.

[36] Nugraha, R. 2016. "Analysis Of The Influence Of Capital Labour Intensive, Investment, Managerial Ownership, Operating Leverage Through Dividend And Financial Leverage As Intervening Variable on Firm Value In Indonesia Non Financial Sector Companies”. Jurnal Riset Manajemen Sains Indonesia (JRMSI), Vol. Vol 7, No. 1, No., hlm: 1-21.

[37] Nurhayati, M. 2013. "Profitabilitas, Likuiditas dan Ukuran Perusahaan Pengaruhnya Terhadap Kebijakan Dividen dan Nilai Perusahaan Sektor Non Jasa”. Jurnal Keuangan \& Bisnis Program Studi Magister Manajemen Sekolah Tinggi IImu Ekonomi Harapan, Vol. 5, No. 2, hlm: 144-153.

[38] Nurlela, R. 2008. "Pengaruh Corporate Social Responsibility Terhadap Nilai Perusahaan Dengan Prosentase Kepemilikan Manajemen Sebagai Variabel Moderating". Artikel dipresentasikan pada Simposium Nasional Akuntansi XI, di Pontianak.

[39] Owolabi, S. A., U. E. Inyang, dan E. Uduakobong. 2012. "Determinants of capital structure in Nigerian firms: a theoretical review". Canadian Journal of Accounting and Finance, Vol. 1, No. 1, hlm: 7-15.

[40] Pantow, M. S. R., S. Murni, dan I. Trang. 2015. "Analisa Pertumbuhan Penjualan, Ukuran Perusahaan, Return on Asset, Dan Struktur Modal terhadap Nilai Perusahaan 
yang Tercatat di Indeks LQ 45". Jurnal EMBA: Jurnal Riset Ekonomi, Manajemen, Bisnis dan Akuntansi, Vol. Vol.3 No.1 Maret 2015, , No., hlm: 961-971.

[41] Prasetyorini, B. F. 2013. "Pengaruh ukuran perusahaan, Leverage, price earning ratio dan profitabilitas terhadap nilai perusahaan". Jurnal IImu Manajemen, Vol. 1, No. 1, hIm: 183-196.

[42] Pratama, I. G. G. W., dan N. G. P. Wirawati 2016. " Pengaruh Struktur Modal Dan Profitabilitas Terhadap Nilai Perusahaan Dengan Kepemilikan Manajerial Sebagai Pemoderasi ". E-Jurnal Akuntansi Universitas Udayana, Vol. Vol.15.3. Juni (2016), No., hlm: 1796-1825

[43] Prayoga, E. B., dan L. S. Almilia. 2013. "Pengaruh Struktur Kepemilikan Dan Ukuran Perusahaan Terhadap Pengungkapan Manajemen Risiko". Jurnal Akuntansi dan Keuangan, Vol. 4, No. 1, hlm: 1-19.

[44] Primantara, A. N. A. D. Y., dan A. N. A. D. Y. Primantara. 2016. "Pengaruh Likuiditas, Profitabilitas, Risiko Bisnis, Ukuran Perusahaan, dan Pajak Terhadap Struktur Modal pada Perusahaan Rokok yang Terdaftar di BEl”, Universitas Udayana.

[45] Putra, A. N. D. A., dan P. V. Lestari. 2016. "Pengaruh Kebijakan Dividen, Likuiditas, Profitabilitas dan Ukuran Perusahaan terhadap Nilai Perusahaan”. E-Jurnal Manajemen Unud, Vol. Vol. 5, No.7, No., hlm: 4044 - 4070.

[46] Putri, R. W., dan C. F. Ukhriyawari. 2016. "Pengaruh Likuiditas, Leverage Dan Profitabilitas Terhadap Nilai Perusahaan Pada Perusahaan Telekomunikasi Yang Terdaftar Di Bursa Efek Indonesia Tahun 2012-2014”. BENING, Vol. 3 (1) 2016, No., hIm: 52-73.

[47] Rahmawati, A. D. 2015. "Pengaruh Ukuran Perusahaan, Profitabilitas, Struktur Modal, Dan Keputusan Investasi Terhadap Nilai Perusahaan (Studi Pada Perusahaan Sektor Properti, Real Estate, Dan Building Construction Yang Terdaftar Di Bursa Efek Indonesia (Bei) Periode 2010-2013)”. Jurnal Administrasi Bisnis, Vol. 23, No. 2, hlm: 1-7.

[48] Rompas, G. P. 2013. "Likuiditas Solvabilitas Dan Rentabilitas Terhadap Nilai Perusahaan Bumn Yang Terdaftar Dibursa Efek Indonesia". Jurnal Riset Ekonomi, Manajemen, Bisnis Dan Akuntansi, Vol. 1, No. 3, hlm : 252-262.

[49] Rosiana, G. A. M. E., G. Juliarsa, dan M. M. R. Sari. 2013. "Pengaruh Pengungkapan CSR Terhadap Nilai Perusahaan Dengan Profitabilitas Sebagai Variabel Pemoderasi”. E-Jurnal Akuntansi, Vol. 5, No. 3, hlm: 723-728.

[50] Rubiyani, D. 2016. "Pengaruh Profitabilitas Terhadap Firm Value Dengan Capital Structure Sebagai Variabel Intervening”. Jurnal IImu \& Riset Manajemen, Vol. 5, No. 4, hlm:1-17. 
[51] Safitri, M. 2015. "Analisis Pengaruh Struktur Modal, Likuiditas Dan Efektivitas Terhadapnilai Perusahaan Dan Profitabilitas Sebagai Variabel Intervening Pada Perusahaan Manufaktur", Diponegoro University.

[52] Sambora, M. N. 2014. "Pengaruh Leverage dan Profitabilitas Terhadap Nilai Perusahaan (Studi pada Perusahaan Food and Beverages yang Terdaftar di BEI Periode Tahun 2009-2012)". Jurnal Administrasi Bisnis, Vol. 8, No. 2, hlm.

[53] Saraswathi, I. A. A., I. G. B. Wiksuana, dan H. Rahyuda. 2016. "Pengaruh Risiko Bisnis, Pertumbuhan Perusahaan dan Struktur Modal terhadap Profitabilitas serta Nilai Perusahaan Manufaktur". E-Jurnal Ekonomi dan Bisnis Universitas Udayana, Vol. 5.6 (2016), No., hlm: 1-10.

[54] Sari, R. A. I., dan M. P. Priyadi. 2017. "Pengaruh Leverage, Profitabilitas, Size, dan Growth Opportunity Terhadap Nilai Perusahaan". Jurnal IImu \& Riset Manajemen, Vol. 5, No. 10, hIm: 1-17.

[55] Sari, R. K. 2005. " Faktor-faktor yang Berpengaruh terhadap Nilai Perusahaan dengan Investasi sebagai Variabel Moderating (Di Bursa Efek Jakarta periode 2000 sampai 2002)", Universitas Diponegoro, Semarang.

[56] Setiadewi, K. A. Y., dan I. B. A. Purbawangsa. 2014. "Pengaruh Ukuran Perusahaan dan Leverage Terhadap Profitabilitas dan Nilai Perusahaan". Vol., No., hlm: 506-609.

[57] Sofyaningsih, S., dan P. Hardiningsih. 2011. "Struktur kepemilikan, kebijakan dividen, kebijakan utang dan nilai perusahaan”. Dinamika keuangan dan perbankan, Vol. 3, No. 1, hlm: 68-87.

[58] Soliha, E. 2002. "Pengaruh Kebijakan Hutang terhadap Nilai Perusahaan serta Beberapa Faktor yang Mempengaruhinya". Jurnal Bisnis dan Ekonomi, Vol. 9, No. 2, hIm: 149-163.

[59] Sudiyatno, B., dan E. Puspitasari 2010. "Tobin's Q dan Altman Z-Score Sebagai Indikator Pengukuran Kinerja Perusahaan". Kajian Akuntansi, Vol. Vol. 2. No. 19 , No., hlm: 19-21.

[60] Suharli, M. 2006. "Studi Empiris Terhadap Faktor Yang Mempengaruhi Nilai Perusahaan Pada Perusahaan Go Public Di Indonesia". MAKSI, Vol. 6, No., hlm: 243-256.

[61] Sujoko, dan U. Soebiantoro. 2007. "Pengaruh Struktur Kepemilikan Saham, Leverage, Faktor Intern Dan Faktor Ekstern Terhadap Nilai Perusahaan". Jurnal Manajemen dan Kewirausahaan, Vol. 9, No. 1, hlm: 41-48.

[62] Sunarsih, N. M., dan N. P. Y. Mendra. 2012. "Pengaruh Modal Intelektual Terhadap Nilai Perusahaan Dengan Kinerja Keuangan Sebagai Variabel Intervening Pada 
Perusahaan Yang Terdaftar Di Bursa Efek Indonesia". Simposium Nasional Akuntansi XV. Banjarmasin, Vol., No., hlm: 1-27.

[63] Suroto. 2015. "Pengaruh Keputusan Investasi, Keputusan Pendanaan Dan Kebijakan Dividen Terhadap Nilai Perusahaan (Studi Empiris Pada Perusahaan LQ-45 YangTerdaftar Di Bursa Efek Indonesia Periode Februari 2010-Januari 2015)". Serat Acitya-Jurnal IImiah UNTAG Semarang, Vol. Vol. 4 No. 3, No., hlm: 100-117.

[64] Thaib, I., dan A. Dewantoro. 2017. "Pengaruh Profitabilitas dan Likuiditas Terhadap Nilai Perusahaan dengan Struktur Modal sebagai Variabel Intervening”. Jurnal Riset Perbankan Manajemen dan Akuntansi, Vol. 1, No. 1, hlm: 25-44.

[65] Utami, C. T. U., dan Khairunnisa. 2015. "Pengaruh Ukuran Perusahaan, Profitabilitas, Leverage, Likuiditas Dan Jaminan Obligasi Terhadap Peringkat Obligasi (Studi Pada Perusahaan Yang Terdaftar Di PT. PEFINDO TAHUN 2010 - 2013)". e-Proceeding of Management, Vol. Vol.2, No.3 Desember 2015, No., hlm: 3475-3482.

[66] Wahyudi, U., dan H. P. Pawestri. 2006. "Implikasi struktur kepemilikan terhadap nilai perusahaan: dengan keputusan keuangan sebagai variabel intervening". Simposium Nasional Akuntansi, Vol. 9, No., hlm: 1-25.

[67] Welley, M., dan V. Untu. 2015. "Faktor-Faktor Yang Mempengaruhi Nilai Perusahaan Di Sektor Pertanian Pada Bursa Efek Indonesia Tahun 2010-2013". Jurnal EMBA: Jurnal Riset Ekonomi, Manajemen, Bisnis dan Akuntansi, Vol. 3, No. 1, hlm: 972983.

[68] Wenny. 2015. "Faktor-faktor yang mempengaruhi struktur modal pada perusahaan publik non keuangan". Jurnal Bisnis dan Akuntansi, Vol. 17 1a, No. 19, hlm: 972-983.

[69] Wirjawan, R. S. 2015. "Faktor-faktor yang Mempengaruhi Struktur Modal Perusahaan Manufaktur di Bursa Efek Indonesia”. Jurnal Bisnis Dan Akuntansi, Vol. Vol. 17, No. 1a, November 2015, No., hlm: 1-19.

[70] Wulandari, D. R. 2013. "Pengaruh Profitabilitas, Operating Leverage, Likuiditas terhadap nilai perusahaan dengan struktur modal sebagai intervening". Accounting Analysis Journal, Vol. 2, No. 4, hlm: 455-463.

[71] Yoshendy, A., N. A. Achsani, dan T. N. Maulana. 2016. "Analisis Faktor-Faktor yang Mempengaruhi Struktur Modal Perusahaan Barang Konsumsi di BEI tahun 20022011". Jurnal Bisnis dan Manajemen, Vol. 16, No. 1, hlm: 47-59. 